\title{
New foundation to fund Russian biologists
}

\begin{abstract}
Moscow \& Washington. An international foundation has been formed to keep intact an elite group of Russian biomedical researchers during the current economic crisis in their country. Acting on the assumption that there are no more than " 20 to 30 basic biology labs" in Russia doing first-rate work, Alexander Goldfarb, a biochemist at the Public Health Research Institute (PHRI) in New York, is leading an effort to raise $\$ 5$ million over the next five years for peer-reviewed grants to teams of Russian scientists.

The idea for the American-Russian Biomedical Research Foundation (BRF) grew out of an existing scientific collaboration between Goldfarb, who left the Soviet Union for the United States in the 1970s, and Vadim Nikiforov of the Institute of Molecular Genetics (IMG) in Moscow. In April, the Soros Foundation, a private philanthropy created by George Soros, a wealthy US financier, contributed $\$ 100,000$ to cover BRF's start-up costs, while the Russian Academy of Sciences and the Ministry of Higher Education, Science and Technology have each provided 350,000 rubles $(\$ 3,000)$. Soros has also given $\$ 50,000$, to be converted into rubles, to supplement the salaries of dozens of Russian scientists working collaboratively with US researchers.
\end{abstract}

Goldfarb, who is president of the new foundation, says that it will operate sepa- rately from governments so that the money is not "mainly wasted on the machinery" of administering research. A panel of prominent US scientists will oversee the process of selecting the most promising projects from among proposals submitted to the IMG and then forwarded to the West.

PHRI, a nonprofit research organization conducting research in biology and medicine, will be the foundation's base in the United States. This year its two-person staff will concentrate on raising funds from companies and private organizations concerned about the future health of Russian biomedical research. The Moscow office at the IMG will meanwhile solicit grant applications. If its fund-raising efforts are successful, the foundation would like to make ten research grants, of $\$ 50,000$ each, by 1 September or soon afterwards.

Goldfarb believes that many potential contributors have been deterred because they did not know who to give their money to and whether the funds would be spent properly. $\mathrm{BRF}$ will provide the infrastructure to overcome those problems, he says. Each grant will carry a 40 per cent surcharge, says Goldfarb, "so that we can provide the infrastructure that doesn't exist in Russia". The money will pay for such administrative functions as an accounting and purchasing system, as well as the cost of delivering needed equipment and supplies.

The first test of BRF's infrastructure is a plan to distribute $\$ 1,000$ to each of the 50 or so Russian laboratories collaborating with US partners. With the collapse of the economies of the countries in the former Soviet Union, the US National Science Foundation provided each US grant recipient with an additional $\$ 10,000$ to buy equipment and supplies for its Russian partners. The Fogarty International Center of the US National Institutes of Health sponsors a similar programme. But both agencies prohibit US scientists from paying any part of the salaries of their foreign collaborators.

One difficulty, not yet resolved, is that grant recipients could find their regular budgets reduced and the funds used to support other projects. Russian research managers have considerable discretion over the distribution of rubles, and researchers are worried that BRF could create a situation in which the stronger laboratories are financed by the West and the weaker ones supported by the Russian government."

Goldfarb plays down that possible division, saying that the foundation is only a short-term solution to the problems facing his former colleagues. "Once the Russian economy improves", he says, "then this type of outside support won't be necessary.

Vladimir Pokrowsky \& Jeffrey Mervis

\section{US realigns misconduct offices at NIH}

Washington. The US government announced last week that it will create an Office of Research Integrity as a compromise solution to a continuing dispute over the operation of the scientific misconduct office at the National Institutes of Health (NIH).

The decision to close the Office of Scientific Integrity (OSI) and move its operations out of NIH and into its parent agency, the Department of Health and Human Services (HHS), is meant to address criticism that OSI, as a part of NIH, was too close to the scientific community to be impartial. It will also answer those who argued that OSI lacked the regulatory authority both to investigate and to adjudicate, and that it failed to provide the necessary legal protection to the targets of its investigations. The new Office of Research Integrity will combine the staff and functions of both the OSI and the Office of Scientific Integrity Review (OSIR), an oversight office that has reviewed OSI investigations and proposed sanctions in individual cases.

Those two duties will be better defined and separated under the new arrangement. The investigative division will do the work of the old OSI, but its reports will contain only investigative results and recommended conclusions rather than reaching a conclusion about whether misconduct has occurred. If an investigation does result in a proposed finding of misconduct, the accused researcher can ask for a special hearing, similar to that offered to those who, for whatever reason, face the loss of federal funds.

The new hearings will offer scientists such due-process protection as access to evidence and to an attorney and the right to cross-examine witnesses and to present rebuttal evidence and witnesses. The hearing panel will consist of an HHS administrative law judge and, in cases where the judge wants expert advice on complex scientific issues, two independent researchers. More people will be working on investigating misconduct, especially on the legal side: the new investigative branch will employ six lawyers, compared with one on the current OSI staff.

J. Michael McGinnis, now director of the office of disease prevention and health promotion within the Public Health Service, has been named acting director of the office. A search is under way for a permanent director. Lyle Bivens, the current director of OSIR, will direct the policy division of the new office. Although Jules Hallum, who now runs OSI, has been named acting director of the new investigative division, he may not remain. Hallum, a virologist, is 68 years old and is thinking of retirement.

Hallum fought to keep OSI at NIH, and he is concerned that the merger of OSI and OSIR may reduce the credibility of the investigative process. Although an independent hearing serves an important role when misconduct is uncovered, he says, he is unhappy that no independent review will be conducted when there is no finding of misconduct. Without OSIR as an double check, he asks, "who's going to prove that we aren't whitewashing people?"

Hallum also says that stripping OSI of its adjudicative aspects could "let us get away with less due process" in the investigative phase. But he promises that there will be no reduction in such protection while he is running the operation.

The new office, which is to open on 15 June, will be located in HHS's offices in Rockville, Maryland.

Christopher Anderson 